\title{
Kadar Albumin Pasien Rawat PICU RSAB Harapan Kita Tahun 2010: Dampak Terhadap Mortalitas dan Morbiditas
}

\author{
Agnes Praptiwi, G.Dharma Mulyo, Henny Rosita Iskandar, Yuliatmoko Suryatin \\ PICU RSAB Harapan Kita, Jakarta
}

\begin{abstract}
Latar belakang. Pada anak dengan sakit kritis sering dihubungkan dengan kadar albumin serum yang rendah. Hipoalbuminemia terjadi karena peningkatan kebocoran kapiler sehingga protein hilang ke ruang interstitial. Pada kasus dewasa, kadar albumin yang rendah tersebut dihubungkan dengan mortalitas dan morbiditas pasien rawat Intensive Care Unit (ICU). Pada pasien anak belum banyak data mengenai hal tersebut.

Tujuan. Untuk mendapatkan data kadar albumin serum serta dampaknya terhadap mortalitas dan morbiditas pasien sakit kritis yang dirawat di Pediatric Intensive Care Unit (PICU) Rumah Sakit Anak Bersalin (RSAB) Harapan kita.

Metode. Penelitian kohort retrospektif, kriteria inklusi adalah semua subyek yang dirawat di PICU RSAB Harapan Kita, sejak Januari hingga Desember 2010. Kriteria eksklusi adalah subyek yang tidak terdapat data kadar serum albumin saat masuk ruangan PICU. Terdapat 345 pasien rawat, 290 (84\%) diikutsertakan, berumur 1 bulan hingga 18 tahun. Dikelompokkan pasien hipoalbuminemia, apabila kadar albumin serum $<3,5 \mathrm{~g} / \mathrm{dL}$ dan normoalbuminemia, apabila kadar albumin serum $>3,5 \mathrm{~g} / \mathrm{dL}$. Kedua kelompok dibandingkan terhadap mortalitas dan morbiditas, di antaranya risiko pemakaian ventilator, pemakaian obat inotrop/ vasoaktif, disfungsi lebih dari dua organ dan lama perawatan.

Hasil. Terdapat $190(65,5 \%)$ pasien hipoalbuminemia dan 100 (34,5\%) normoalbuminemia. Sebagian besar berumur 1-12 bulan 118 (40,7\%). Terbanyak laki-laki 153 (54,1\%) dan perempuan 136 (45,9\%). Kelompok hipoalbuminemia mempunyai mortalitas lebih tinggi dibandingkan normoalbuminemia. Risiko pemakaian ventilator dan pemakaian obat inotrop atau vasoaktif yang lebih besar dibandingkan kelompok normoalbuminemia.

Kesimpulan. Lebih dari separuh (65,5\%) anak sakit kritis yang dirawat di PICU RSAB Harapan Kita mempunyai albumin serum $<3,5 \mathrm{~g} / \mathrm{dL}$. Hanya sekitar $37(12,8 \%)$ pasien yang mengalami gizi buruk dan kurang. Hipoalbuminemia ini mempengaruhi mortalitas, penggunaan ventilador dan pemakaian obat inotrop/vasoaktif pasien rawat PICU. Sari Pediatri 2012;14(4):256-9.
\end{abstract}

Kata kunci: hipoalbuminemia, ventilator, normoalbuminemia

\footnotetext{
Alamat korespondensi:

Dr. Agnes Praptiwi, Sp.A. PICU RSAB Harapan Kita. Jl. Letjen S. Parman Kav. 87, Slipi, Jakarta. Telp. (021) 5668284. E-mail: karolin_ junior@yahoo.com
} 
$\mathrm{H}$ ipoalbuminemia umum terjadi pada pasien sakit kiritis yang dirawat di ICU. Sintesis albumin akibat síntesis di hati yang menurun dan atau kehilangan protein yang meningkat (pergeseran distribusi dari ruangan intravaskular ke interstitial) dan pelepasan hormon yang meningkatkan dekstruksi metabolisme albumin serta dihubungkan dengan reaksi inflamasi. Kadar albumin darah yang rendah pada sakit kritis ini menggambarkan kebocoran endotel, jadi bukan menggambarkan malnutrisi.

Anak sakit kritis dengan status gizi kurang dan kadar albumin $<3,5 \mathrm{gr} / \mathrm{dL}$, menggambarkan status nutrisi yang dihubungkan dengan proses penyakit dan/ atau pemulihan atau hambatan dalam penyembuhan luka dan penurunan daya tahan tubuh. Jadi setiap upaya untuk meningkatkan kadar albumin dalam keadaan kebocoran (sepsis berat, dengue, SIRS) akan sia-sia. Jika kadar albumin dalam perawatan kembali normal bisa menggambarkan perbaikan kebocoran endotelnya.

Anak dengan hipoalbuminemia mudah terjadi infeksi akut yang disertai efusi pleura yang luas. ${ }^{1}$ Albuminemia mempengaruhi mortalitas dan morbiditas di antaranya lama rawat, pemakaian ventilator, dan disfungsi organ. ${ }^{2}$ Penting mengetahui prognosis pasien rawat PICU sejak awal rawat. Hal tersebut berguna untuk penyampaian informasi kepada keluarga pasien, dan menentukan tata laksana pasien selanjutnya. Skor Pelod dapat digunakan untuk untuk menilai prediksi kematian, tetapi tidak dapat digunakan untuk memperkirakan lama perawatan di PICU. ${ }^{3}$

\section{Metode}

Penelitian secara kohort retrospektif. Kriteria inklusi adalah semua subyek yang dirawat di PICU RSAB Harapan Kita, sejak Januari hingga desember 2010. Kriteria eksklusi adalah subyek yang tidak terdapat data kadar serum albumin saat masuk ruangan PICU. Terdapat 345 pasien rawat PICU, 290 (84\%) diikutsertakan dalam penelitian dengan subyek berumur 1 bulan hingga 18 tahun.

Variabel bebas adalah kadar albumin serum yang diperiksa saat awal masuk ruang PICU. Subyek dikelompokkan dalam hipoalbuminemia, apabila kadar albumin $<3,5 \mathrm{~g}$ g/dL, dan normoalbuminemia apabila $\geq 3,5 \mathrm{~g} / \mathrm{dL}$. Sebagai variabel perancu adalah jenis kelamin, umur pasien, status gizi, disfungsi organ, dan diagnosis subyek penelitian. Kategori umur pasien dibagi dalam tiga kelompok berdasarkan kekerapannya, yaitu umur $<12$ bulan, 12-60 bulan, dan $>60$ bulan. Status gizi subyek berdasarkan kekerapannya dibagi dua kelompok yaitu, kelompok gizi buruk dan gizi kurang serta kelompok gizi baik dan gizi lebih. Diagnosis pasien dikelompokkan menjadi tiga berdasarkan berat penyakit yaitu kelompok syok dan pneumonia, kelompok kasus neurologi, gastrohepatologi dan kasus bedah, serta kelompok subyek dengan demam berdarah dengue (DBD) tanpa syok. Disfungsi organ pada diagnosis subyek dikelompokkan menjadi $\geq 2$ dan $<2$ organ yang terlibat.

Variabel tergantung adalah mortalitas, pola napas, dan pemakaian obat inotrop/vasoaktif. Pola napas dikelompokkan menjadi kelompok spontan, baik dengan atau tanpa oksigen. Sedangkan kelompok napas ventilator adalah subyek dengan pola napas menggunakan Endotracheal Tube (ETT) baik terpasang atau tidak dengan ventilator. Pemakaian obat inotrop/ vasoaktif, dikelompokkan menjadi dua. Kelompok obat inotrop/vasoaktif adalah subyek yang selama perawatan di PICU pernah mendapat terapi obat inotrop dan atau vasoaktif.

\section{Analisis statistik}

Hubungan bivariat antara albumin dengan mortalitas, pola napas, dan pemakaian obat inotrop/vasoaktif diuji dengan uji chi square atau uji Fisher. Untuk mengontrol variabel perancu dan mendapatkan adjusted $O R$ dari albumin digunakan analisis multivariat analisis regresi logistik untuk konsep etiologi. Software yang digunakan adalah SPSS.

\section{Hasil}

Antara Januari hingga Desember 2010 terdapat 345 pasien pasien rawat PICU RSAB Harapan Kita, 55 $(16 \%)$ subyek tidak diikutsertakan dalam penelitian Data karakteristik demografi 290 pasien penelitian tertera pada Tabel 1.

Tabel 2 memperlihatkan crude OR (Odd rasio) dan adjusted $O R$ antara kadar albumin dengan pola napas serta pemakaian obat inotrop/vasoaktif. Kemudian analisis bivariat, hubungan antara variabel yang diteliti dengan mortalitas. Berdasarkan analisis bivariat variabel yang akan dibandingan dengan variabel multivariat 
adalah diagnosis pasien, status gizi, jenis kelamin, usia, dan disfungsi organ.

Tabel 1. Data karakteristik demografis pasien penelitian

\begin{tabular}{|c|c|c|}
\hline Keterangan & Jumlah & $\%$ \\
\hline Jenis kelamin & 154 & 53,1 \\
\hline $\begin{array}{l}\text { laki } \\
\text { perempuan }\end{array}$ & 136 & 46,9 \\
\hline Umur pasien (bulan) & 118 & 40,7 \\
\hline$<12$ & 90 & 31 \\
\hline $\begin{array}{l}12-60 \\
60\end{array}$ & 82 & 28,3 \\
\hline Status gizi & 37 & 12,8 \\
\hline $\begin{array}{l}\text { Buruk dan kurang } \\
\text { Baik dan lebih }\end{array}$ & 253 & 87,2 \\
\hline Diagnosis pasien penelitian & 136 & 46,9 \\
\hline Syok dan pneumonia & 92 & 31,7 \\
\hline $\begin{array}{l}\text { Kasus neurologi, kasus bedah dll } \\
\text { DBD }\end{array}$ & 62 & 21,4 \\
\hline Disfungsi organ & 157 & 54,1 \\
\hline $\begin{array}{l}>2 \\
<2\end{array}$ & 133 & 45,9 \\
\hline Kadar albumin serum $(\mathrm{g} / \mathrm{dL})$ & 190 & 65,5 \\
\hline $\begin{array}{l}<3,5 \\
>3,5\end{array}$ & 100 & 34,5 \\
\hline Pola napas pasien & 81 & 27,9 \\
\hline $\begin{array}{l}\text { Ventilator } \\
\text { Spontan }\end{array}$ & 209 & 72,1 \\
\hline Obat inotrop/vasoaktif & 136 & 46,9 \\
\hline $\begin{array}{l}\text { Dengan obat } \\
\text { Tanpa obat }\end{array}$ & 154 & 53,1 \\
\hline Lama perawatan (hari) & 47 & 16,2 \\
\hline$<2$ & 164 & 56,5 \\
\hline $2-6$ & 79 & 27,2 \\
\hline$>6$ & & \\
\hline Mortalitas & 228 & 78,6 \\
\hline Hidup & 62 & 21,4 \\
\hline Meninggal & & \\
\hline
\end{tabular}

Dengan multivariat regresi logistik kategorik dapat disimpulkan bahwa kadar albumin serum mempunyai pengaruh terhadap mortalitas, pola napas pasien dengan penggunaan ventilator dan pemakaian obat inotrop/vasoaktif selama perawatan di PICU RSAB Harapan Kita.

\section{Pembahasan}

Albumin adalah suatu protein yang berperan penting dalam tubuh untuk mempertahankan $\mathrm{pH}, \mathrm{SBE}$, dan HCO3- dalam batas normal. Pada pasien sehat, kontribusi albumin adalah $80 \%$ terhadap tekanan koloid onkotik plasma. Pada pasien sakit kritis, hipoalbuminemia dapat menyebabkan edema saat tekanan hidrostatik meningkat, ${ }^{4}$ dan menurunnya ikatan dengan ikatan molekul tinggi protein lainnya.

Penyebab hipoalbuminemia adalah sekunder dari gangguan sintesis protein pada malnutrisi kalori, penyakit hati kronis atau kehilangan proteinuria yang meningkat misalnya pada protein losing enteropathy, luka bakar atau iatrogenik. Pada anak hipoalbuminemia mudah terjadi infeksi akut disertai efusi pleura yang luas. ${ }^{1}$

Insiden hipoalbuminemia pada penelitian kami $65,5 \%$. Hipoalbuminemia pada penelitian kami mempengaruhi mortalitas, penggunaan ventilator, dan pemakaian obat inotrop/vasoaktif. Horowitz dkk, ${ }^{2}$ meneliti dampak albuminemia pada 225 anak sakit kritis juga menyimpulkan secara bermakna pengaruh mortalitas dan morbiditas di antaranya lama rawat, pemakaian ventilator, dan disfungsi organ.

Hipoalbuminemia saat masuk rumah sakit sudah umum terdapat pada pasien sakit kritis, tetapi merupakan prediktor independen terhadap mortalitas.

Tabel 2. Dampak albumin terhadap mortalitas dan morbiditas

\begin{tabular}{|c|c|c|c|c|c|c|c|c|}
\hline \multirow{2}{*}{ Keterangan } & \multicolumn{2}{|c|}{ Kadar albumin (\%) } & \multirow{2}{*}{$\mathrm{p}$} & \multicolumn{2}{|r|}{ Crude } & \multirow{2}{*}{$\mathrm{p}$} & \multicolumn{2}{|c|}{ Adjusted } \\
\hline & $<3,5 \mathrm{~g} / \mathrm{dL}$ & $>3,5 \mathrm{~g} / \mathrm{dL}$ & & OR & $\operatorname{IK}(95 \%)$ & & OR & $\operatorname{IK}(95 \%)$ \\
\hline Meninggal & $48(25,4)$ & $14(13,9)$ & 0,024 & 2,12 & $(1,10-4,06)$ & 0,009 & 2,49 & $1,23-4,95$ \\
\hline Hidup & $141(74,6)$ & $87(86,1)$ & & & & & & \\
\hline \multicolumn{9}{|l|}{ Pola napas } \\
\hline Ventilator & $60(31,7)$ & $21(20,8)$ & 0,055 & 1,78 & $(1,01-3,13)$ & 0,055 & 1,78 & $1,01-3,13$ \\
\hline Spontan & $129(68,3)$ & $80(79,2)$ & & & & & & \\
\hline \multicolumn{9}{|c|}{ Obat inotrop/vasoaktif } \\
\hline Dengan obat & $98(51,9)$ & $38(37,6)$ & 0,026 & 1,79 & $(1,09-2,92)$ & 0,061 & 1,78 & $0,97-3,27$ \\
\hline Tanpa obat & $91(48,1)$ & $63(62,4)$ & & & & & & \\
\hline
\end{tabular}


Beberapa penelitian menunjukkan kadar albumin serum dapat merupakan prediktor prognosis pada pasien dewasa. Pada bayi dengan berat lahir sangat rendah, kadar albumin tidak berhubungan dengan mortalitas dan morbiditas. Serum albumin yang rendah sekali, secara statistik bermakna mempunyai korelasi terbalik dengan mortalitas. ${ }^{10}$ Pada penelitian kami insiden albuminemia dijumpai $65,5 \%$ dan $12,8 \%$ subyek berstatus gizi kurang dan buruk.

Penentuan prognosis pasien yang dirawat di PICU memerlukan alat yang obyektif. Hal tersebut bertujuan untuk memudahkan memberikan informasi kepada keluarga pasien, serta memahami keadaan penyakit. Skor PELOD dapat digunakan untuk menilai prediksi kematian pasien rawat PICU tetapi tidak dapat digunakan untuk lama rawat. $^{3}$ Angka skor PELOD yang lebih tinggi akan meningkatkan risiko terjadi gagal fungsi organ multipel. ${ }^{7}$ Gagal ginjal akut yang terjadi pasca operasi jantung mempunyai risiko mortalitas. Gagal fungsi lebih dari tiga organ berhubungan dengan lebih dari separuh angka mortalitas. Kadar albumin serum yang rendah merupakan prediktor mortalitas. ${ }^{8}$ Kadar albumin serum saat masuk rumah sakit $<2,6$ $\mathrm{g} / \mathrm{dL}$, merupakan prediktor independen terhadap morbiditas dan mortalitas pada pasien trauma. Dengan umur yang bertambah dan kadar albumin yang lebih rendah merupakan prediktor infeksi dan mortalitas. ${ }^{11}$ Hipoalbuminemia berhubungan kuat dengan morbiditas. ${ }^{12}$ Pada penelitian kami 21,4\% meninggal dunia dan $54,1 \%$ mengalami disfungsi lebih dari dua organ.

Pemberian albumin dapat memperbaiki fungsi organ pada pasien sakit kritis dengan hipoalbuminemia. Akan terjadi sedikit balans positif cairan dan ditoleransi lebih baik pada pemberian secara enteral. ${ }^{6}$ Tentang keamanan pemberian albumin pada pasien sakit kritis telah diteliti banyak pihak, dan sebagian menyatakan tidak terdapat perbedaan terhadap mortalitas dan lama rawat dengan pemberian human albumin pada pasien yang memerlukan penggantian cairan. ${ }^{4}$ Kasus hipoalbuminemia terbanyak berhubungan dengan kehilangan protein melalui intestine (fecal alpha-1-AT). ${ }^{5}$

Disimpulkan bahwa hipoalbuminemia umum terjadi pada anak sakit kritis yang dirawat di PICU RSAB Harapan Kita. Kadar albumin $<3,5$ gram/dL mempengaruhi mortalitas, pemakaian ventilator, dan penggunaan obat inotrop. Disarankan untuk melakukan penelitian lanjutan tentang berapa cut of point kadar albumin pada anak dengan sakit kritis yang berpengaruh terhadap mortalitas.

\section{Daftar pustaka}

1. Prais D, Amir J, Harel Liora. Association of Hipoalbuminemia with the presence and size of pleural effusion in children with pneumonia. Pediatrics 2008;121;e533.

2. Horowitz IN, Tai K. Hipoalbuminemia in critically ill children. Arch Pediatr Adolesc Med 2007;161:1048-52.

3. Metta D, Subardja D, Somasetia HD. Penggunaan skor pediatrik logistic organ dysfunction (PELOD) untuk menentukan prognosis penderita di Pediatric Intensive Care Uni (PICU) Rumah Sakit Hasan Sadikin Bandung. Abstrak.

4. Bradley P, Fuhrman, Jerry J, Zimmerman, Carcillo JA. Fuhrman and Zimmerman. Pediatric critical care. Edisi keempat. Philadelphia: W.B. Saunders \& Co; 2011.h. 1215-944.

5. Klar A, Shoseyov d, Brand A. Intestinal protein loss and Hipoalbuminemia in children with pneumonia. J Pediatr Gastroenterol Nutr 2003;37:120-3.

6. Dubois M, Jimenez C, Melot C. Albumin administration improves organ function in critically ill hypoalbuminemic patients: A prospective, randomized, controlled, pilot study. Crit care med 2006;34:2536-40.

7. Hendra, Runtunuwu AL, Manoppo JIC. Pediatric logistic organ dysfunction (PELOD) score as prognosis of multiple organ failure in sepsis. Pediatr Indones 2010;50:226-31.

8. Williams D.M, Sreedhar S.S, Mickell J.J. Acute Kidney Failure. Arch Pediatr Adolesc Med 2002;156:893-900.

9. Mayer A, Skellett S, Taylor D. Hypoalbuminaemia in critically ill children: incidence, prognosis, and influence on the anion gap. Arch Dis Child 2003;88:419-22.

10. Morris I, McCallion N, El-Khuffash A. Serum albumin and mortality in very low birth weight infants 2008;93:F310F12.

11. Sung J, Bochicchio GV, Joshi M. Admission serum albumin is predicitve of outcome in critically ill trauma patients. Am Surg 2004;70:1099-102.

12. Vincent J, Dubois M, Navickis RK. Hipoalbuminemia in acute illness: is there a rationale for intervention?A meta-analysis of cohort studies and controlled trials. Ann Surg 2003;237:319-34.

13. Williams, DM, Sreedhar, S.S, Mickell, J.J. Acute kidney failure. A pediatric experience over 20 years. Arch Pediatr Adolesc Med 2002;156:893-900. 